\title{
Evolution by the Grassroots
}

\section{By Olivia Judson}

Editor's Note: This piece originally appeared on March 2, 2010, in The New York Times on-line Opinionator column and is republished here with permission.

Imagine the Earth without grasses.

There would be no lawns or meadows. No prairies. No savannahs or steppes. No wheat fields or rice paddies. No sugar cane.

No sheep, elephants or horses.

No people.

We live in the age of grass. Indeed, from our point of view, the evolution of grasses was one of the most momentous events in the history of the Earth. Which is why I'm nominating them for Life-form of the Month: March.

Let's limber up with a few facts. In general, grasses spread their pollen by wind, so they are not dependent on bees or other insects. Grasses also grow fast, and can easily colonize patches of bare ground, or move into a landscape after a fire. They can withstand being eaten (or mown) better than most other plants, because their leaves grow from the base, not the top.

Like all plants, they make energy from the sun by means of photosynthesis. However, grasses have repeatedly evolved a variation-known as $\mathrm{C} 4$ photosynthesis- that uses less water, and is thus a particular advantage in hot, dry places, or when carbon dioxide levels are low. This has allowed them to flourish in difficult habitats, like rocky outcrops and dry soils. One other detail: grasses fill their leaves with silica. That is, they are factories for tiny opals.

As a group, grasses have been wildly successful. Today, the grass family contains more than 10,000 species-that's more species of grass than species of bird-and grasslands cover about a third of the planet's landmasses. ("Grassland" refers to an ecosystem, like prairie, where grasses dominate; it doesn't mean they are the only plants there.) Grasses can be tall (think bamboo) or short (think lawns), and they include our most important crops. Rice, wheat, rye, oats, maize, millet, barley, sorghum and sugar cane are all grasses.

We humans are dependent on grasses: we get more than half our calories directly from the tetrad of rice, wheat, maize and sugar cane, and we feed grasses to our sheep, goats, horses and cows.

But I'm getting ahead of myself.
The early history of grasses is obscure. However, we do know that they blew onto the scene relatively late-around 80 million years ago, shortly before the dinosaurs went extinct. In evolutionary terms, that's yesterday.

And having arrived late, their rise to prominence got off to a slow start. If you climbed into your time machine and set the dial for 55 million years ago, you wouldn't find much in the way of grasses when you got there: at that point, they were still minor players on the Earth's stage. But by 15 million years ago, that had changed. Grasslands had become abundant.

Exactly why this happened is a matter of debate. But whatever the reasons, the effect on other life-forms has been profound.

Grasses affect the landscape both above and below the surface of the Earth. Below: they alter the texture of the soil. Grassland soil is typically characterized by small crumbs that are rich in organic matter. This is partly due to the way that grass roots grow, and partly due to the animals that grasses encourage-like earthworms and insects. Many of our richest agricultural lands were made so by grasses.

Above ground, grasslands create wide open spaces where large animals can run fast and go about in big herds. Hence, the spread of grasses triggered the evolution of big, herding mammals with long legs and hooves - horses and antelopes, for example. Moreover, all those opals are hard to eat: they wear down teeth. So the rise of grasses was also met with the evolution of "hypsodonty"- - long teeth.

(Just as grasslands sculpted the evolution of certain mammals, so too mammals sculpted the evolution of grasslands. Many mammals eat young trees-and thus prevent trees from invading a grassy area. Elephants can-and sometimes do-uproot big trees. The high opal-content of grasses is, in part, an evolved response to being eaten.)

Now pause for a moment to imagine these savannahs with their big herds of galloping mammals. For these are also the landscapes in which, perhaps, our earliest ancestors stood on two legs and learned to hunt-though again, this is a matter of debate.

Yet regardless of how much grasses shaped our earliest evolution, in the recent past they have transformed us. We usually talk of our domestication of grasses, and the ways in which we have evolved them: we have made plants with bigger, more nutritious seeds that don't fall to the ground, for example. 
But their effect on us has been far more profound. Our domestication of grasses, 10,000 years ago or so, allowed the building of the first cities, and marks the start of civilization as we know it. Grasses thus enabled the flowering of a new kind of evolution, a kind not seen before in the history of life: the evolution of human culture.

\section{Author's Notes}

Grasses are an extremely complex subject with a vast literature, and I have therefore had to skate over some aspects of their biology and omit others. Apologies if I've left out anybody's favorite grassy attribute.

The basic features of grasses can be found in any botany textbook. I drew on Willis, K. J. and McElwain, J. C. 2002. "The Evolution of Plants." Oxford University Press. See especially pages 207-213. For the number of grass species, see the Grass Phylogeny Working Group 2001. "Phylogeny and subfamilial classification of the grasses (Poaceae)." Annals of the Missouri Botanical Garden 88:373-457. For grasses making opals, see Twiss, P. C. 2001. "A curmudgeon's view of grass phytolithology." Pages 7-25 of "Phytoliths: Applications in Earth Sciences and Human History." Edited by Meunier, J. D. and Colin, F. Taylor and Francis.

For a comprehensive overview of the advantages and evolution of $\mathrm{C} 4$ photosynthesis in grasses as well as other plants, see Sage, R. F. 2004. "The evolution of C4 photosynthesis." New Phytologist 161:341-370. For the repeated evolution of $\mathrm{C} 4$ photosynthesis in grasses in particular, see Christin, P.-A. et al. 2007. "C4 photosynthesis evolved in grasses via parallel adaptive genetic changes." Current Biology 17:1241-1247.

For the proportion of the landmasses covered by grasslands, see Shantz, H. L. 1954. "The place of grasslands in the Earths' cover of vegetation." Ecology 35:143-145. This paper also discusses the enrichment of the soils due to grasses.

The fact that rice, wheat, maize and sugar cane provide more than half of our calories, comes from fact sheets of the Food and Agriculture Organization of the United Nations. See this (FAO factsheet on world calories: http://www.fao. org/economic/ess/chartroom-and-factoids/chartroom/ 93-world-calories-total/en/) and this (Food and Agriculture Statistics Global Outlook: http://faostat.fao.org/Portals/ _Faostat/documents/pdf/world.pdf).

Exactly when grasses originated is still under discussion. Most authors seem to agree that it was in the late Cretaceous, but the details are not entirely clear. I have taken my estimate from Prasad, V. et al. 2005. "Dinosaur coprolites and the early evolution of grasses and grazers." Science 310: 1177-1180. This is based on grass fossils. For an earlier origin of grasses based on DNA evidence, see Vicentini, A. et al. 2008. "The age of grasses and clusters of origins of $\mathrm{C} 4$ photosynthesis." Global Change Biology 14:2963-2977.
For the rise of grasslands, see Jacobs, B. F., Kingston, J. D. and Jacobs, L. L. 1999. "The origin of grass-dominated ecosystems." Annals of the Missouri Botanical Garden 86:590-643. For the debate over why grasses became prominent-including the argument that grasses themselves have been an important force of nature-see Retallack, G. J. 2001. "Cenozoic expansion of grasslands and climatic cooling." Journal of Geology 109:407-426. This paper also discusses the ways in which grasses alter soils. For a beautiful description of the evolution of grasses, and for a discussion of the advantages of different types of photosynthesis, see pages 276-303 of Morton, O. 2007. "Eating the Sun: How Plants Power the Planet." Fourth Estate.

For grasses and long teeth in mammals, see Stebbins, G. L. 1981. "Coevolution of grasses and herbivores." Annals of the Missouri Botanical Garden 68:75-86. Also see Jervall, J. and Fortellus, M. 2002. "Common mammals drive the evolutionary increase of hypsodonty in the Neogene." Nature 417:538-540. For the impact that mammals can have on grasslands, including the role of elephants, see Sankaran, M., Ratnam, J. and Hanan, N. 2008. "Woody cover in African savannas: the role of resources, fire and herbivory." Global Ecology and Biogeography 17:236-245. For opals being a response to being eaten, see McNaughton, S. J. and Tarrants, J. L. 1983. "Grass leaf silicification: natural selection for an inducible defense against herbivores." Proceedings of the National Academy of Sciences USA 80:790-791. See also Bouchenak-Khelladi, Y. et al. 2009. "The origins and diversification of $\mathrm{C} 4$ grasses and savanna-adapted ungulates." Global Change Biology 15:2397-2417.

The role that early grasslands may have played in human evolution is hotly debated. For a good overview of the status of different hypotheses, see Bobe, R. and Behrensmeyer, A. K. 2004. "The expansion of grassland ecosystems in Africa in relation to mammalian evolution and the origin of the genus Homo." Palaeogeography, Palaeoclimatology, Palaeoecology 207:399-420.

Our impact on grasses has been extensively studied; see, for example, Glémin, S. and Bataillon, T. 2009. "A comparative review of the evolution of grasses under domestication." New Phytologist 183:273-290. So has the impact that grasses have had on us: see, for example, Diamond, J. 2002. "Evolution, consequences, and future of plant and animal domestication." Nature 418:700-707.

Many thanks to Jonathan Swire for insights, comments and suggestions.

From The New York Times, (C) March 2, 2010. The New York Times. All rights reserved. Used by permission and protected by the Copyright Laws of the United States. The printing, copying, redistribution, or retransmission of the Material without express written permission is prohibited. Article originally published at http:// opinionator.blogs.nytimes.com/2010/03/02/evolution-by-the-grassroots/ ?hp. 
Olivia Judson is an evolutionary biologist and Nerw York Times on-line commentator who writes every Wednesday about the influence of science and biology on modern life. She is the author of Dr. Tatiana's Sex Advice to All Creation: The Definitive
Guide to the Evolutionary Biology of Sex. Ms. Judson has been a reporter for The Economist and has written for a number of other publications, including Nature, The Financial Times, The Atlantic, and Natural History. She is a research fellow in biology at Imperial College London. 